\title{
Charge Localization in the Lithium Iron Phosphate Li3Fe2(PO4)3at High Voltages in
} Lithium-Ion Batteries

Younesi, Reza; Christiansen, Ane Sælland; Loftager, Simon; García Lastra, Juan Maria; Vegge, Tejs; Norby, Poul; Holtappels, Peter

\section{Published in:}

ChemSusChem (Print)

Link to article, DOI:

$10.1002 /$ cssc. 201500752

Publication date:

2015

Document Version

Peer reviewed version

Link back to DTU Orbit

Citation (APA):

Younesi, R., Christiansen, A. S., Loftager, S., García Lastra, J. M., Vegge, T., Norby, P., \& Holtappels, P. (2015). Charge Localization in the Lithium Iron Phosphate $\mathrm{Li}_{2} \mathrm{Fe}_{2}(\mathrm{PO})$ at High Voltages in Lithium-lon Batteries. ChemSusChem (Print), 8(19), 3213-3216. https://doi.ơg/1041002/cssc.201500752

\section{General rights}

Copyright and moral rights for the publications made accessible in the public portal are retained by the authors and/or other copyright owners and it is a condition of accessing publications that users recognise and abide by the legal requirements associated with these rights.

- Users may download and print one copy of any publication from the public portal for the purpose of private study or research.

- You may not further distribute the material or use it for any profit-making activity or commercial gain

- You may freely distribute the URL identifying the publication in the public portal 


\title{
Charge localization in $\mathrm{Li}_{3} \mathrm{Fe}_{2}\left(\mathrm{PO}_{4}\right)_{3}$ at high voltages
}

\author{
Reza Younesi, ${ }^{[a]}$ Ane Christiansen, ${ }^{[a]}$ Simon Loftager,${ }^{[a]}$ Juan Maria García-Lastra, ${ }^{[a]}$ Tejs Vegge ${ }^{[a]}$ \\ Poul Norby, ${ }^{[a]}$ and Peter Holtappels ${ }^{[a]}$
}

\begin{abstract}
Possible changes in oxidation state of oxygen ion in $\mathrm{Li}_{3} \mathrm{Fe}_{2}\left(\mathrm{PO}_{4}\right)_{3}$ at high voltages in Li-ion batteries is here studied using experimental and computational analysis. Results obtained from synchrotron-based hard X-ray photoelectron spectroscopy and density functional theory showed that oxidation state of $\mathrm{O}^{2-}$ ions altered to higher oxidation states $\left(0^{\delta-}, \delta<2\right)$ upon charging $\mathrm{Li}_{3} \mathrm{Fe}_{2}\left(\mathrm{PO}_{4}\right)_{3}$ to $4.7 \mathrm{~V}$.
\end{abstract}

Three-dimensional frameworks cathode materials based on transition metal and polyanions have been the topic of an intensive research in the battery community in recent years, since they can provide long-term structure stability and higher redox potential compared to oxides. ${ }^{[1]} \mathrm{NASICON}$ (Na-super-ionic conductors) structure as a member of this family are known to possess fast ion transport due to the elasticity of the framework as well as large, three-dimensionally interconnected conduction pathways. ${ }^{[1]}$ For example, $\mathrm{Li}_{3} \mathrm{~V}_{2}\left(\mathrm{PO}_{4}\right)_{3}$ has been proposed as a benchmark providing promising results. ${ }^{[2]} \mathrm{Li}_{3} \mathrm{Fe}_{2}\left(\mathrm{PO}_{4}\right)_{3}$ as an iron-based alternative is another interesting candidate with NASICON structure, which can host up to 1.8 additional $\mathrm{Li}^{+}$ions (redox couple of $\mathrm{Fe}^{3+} / \mathrm{Fe}^{2+}$ ) with great reversibility and a lithiation plateau at $2.8 \mathrm{~V} .^{[3-7]}$ However, reversible delithiation of $\mathrm{Li}_{3} \mathrm{Fe}_{2}\left(\mathrm{PO}_{4}\right)_{3}$ at high potentials has not yet been successfully achieved. In this work, we will exploit the possible lithium extraction from $\mathrm{Li}_{3} \mathrm{Fe}_{2}\left(\mathrm{PO}_{4}\right)_{3}$ using a combined computational and spectroscopy analysis. Synchrotron-based hard x-ray photoelectron spectroscopy (HAXPS) is used to investigate changes in the composition and oxidation state of the pristine materials after charging to $4.7 \mathrm{~V}$. Density functional theory (DFT) calculations including Hubbard corrections (DFT+U) are performed in order to study the localization of the positive holes generated in $\mathrm{Li}_{3} \mathrm{Fe}_{2}\left(\mathrm{PO}_{4}\right)_{3}$ as $\mathrm{Li}^{+}$ions are extracted. In comparison, extraction of $\mathrm{Li}^{+}$from $\mathrm{Li}_{3} \mathrm{~V}_{2}\left(\mathrm{PO}_{4}\right)_{3}$ is also investigated using DFT calculations.

Figure 1 shows the charge curve of a $\mathrm{Li}_{3} \mathrm{Fe}_{2}\left(\mathrm{PO}_{4}\right)_{3}$ electrode oxidized to $4.7 \mathrm{~V}$. The plateau at about $4.5 \mathrm{~V}$ could indicate a delithiation process, since i) the length of the plateau is similar to the theoretical capacity for extraction of two $\mathrm{Li}^{+}$, and ii) in situ XRD have shown a small volume contraction indicative of $\mathrm{Li}^{+}$extraction. ${ }^{[8]}$ However, subsequent discharge of $\mathrm{Li}_{3} \mathrm{Fe}_{2}\left(\mathrm{PO}_{4}\right)_{3} \mathrm{materials} \mathrm{has}$ shown to fail, which makes the process questionable. ${ }^{[8]}$ Therefore, in order to investigate the origin of the $4.5 \mathrm{~V}$ plateau in more detail, HAXPES measurements were performed on a $\mathrm{Li}_{3} \mathrm{Fe}_{2}\left(\mathrm{PO}_{4}\right)_{3}$ electrode charged to $4.7 \mathrm{~V}$. A $\mathrm{Li}_{3} \mathrm{Fe}_{2}\left(\mathrm{PO}_{4}\right)_{3}$ electrode charged to $5.2 \mathrm{~V}$ was also investigated in order to have a sample with clear evidence of electrolyte decomposition for comparison (see inset in Figure 1).

Figure 1. Charge curve of a $\mathrm{Li}_{3} \mathrm{Fe}_{2}\left(\mathrm{PO}_{4}\right)_{3}$ electrode oxidized to $4.7 \mathrm{~V}$. The inset shows the charge curve of an electrode oxidized up to 5.2 $\mathrm{V}$, where the dotted line indicates the theoretical capacity for extraction of $2 \mathrm{Li}^{+}$ions.

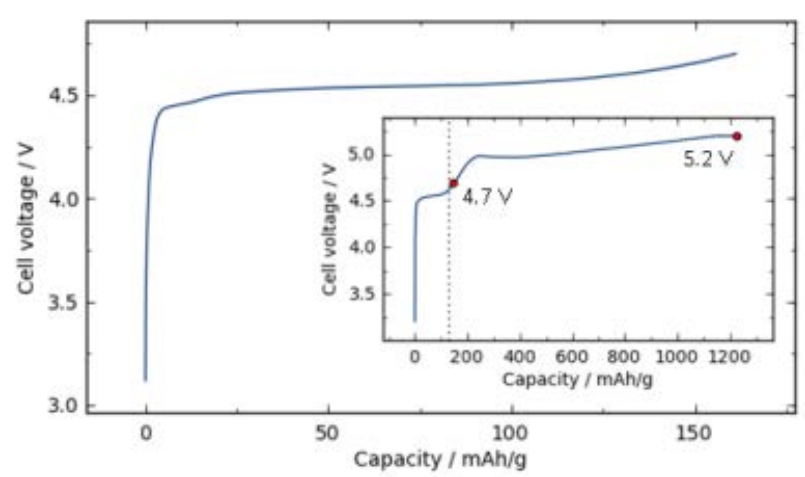

Figure 2a-2d show core-level HAXPES spectra of carbon, fluorine, oxygen, and phosphorus of pristine and charged samples. The C1s, F1s, O1s, and P2p spectra of the pristine sample represent a composite of $\mathrm{Li}_{3} \mathrm{Fe}_{2}\left(\mathrm{PO}_{4}\right)_{3}$, carbon black, and PVdF binder ${ }^{[9,10]}$, as assigned in Figure 2 (Note that each $P 2 p$ peak contains the spin-orbit doublet for $P 2 p_{1 / 2}$ and $P 2 p_{3 / 2}$ ).

After charging the $\mathrm{Li}_{3} \mathrm{Fe}_{2}\left(\mathrm{PO}_{4}\right)_{3}$ electrode to $4.7 \mathrm{~V}$, the $\mathrm{F} 1 \mathrm{~s}$ and $\mathrm{C} 1 \mathrm{~s}$ spectra are slightly changed. The $\mathrm{C} 1 \mathrm{~s}$ spectrum of the charged sample, compared to that of the pristine sample, reveals minor contributions from hydrocarbon, $\mathrm{C}-\mathrm{O}, \mathrm{C}=\mathrm{O} / \mathrm{O}-\mathrm{C}-\mathrm{O}, \mathrm{O}-\mathrm{C}=\mathrm{O}$, and $\mathrm{CO}_{3}$ species. ${ }^{[9,10]}$ However, these changes are very small implying that the solvent decomposition is negligible at $4.7 \mathrm{~V}$. Likewise, in the F1s spectrum of the charged sample a new, small peak, $\mathrm{Li}_{x} \mathrm{PF}_{y} \mathrm{O}_{z}$, appeared, which is originated from minor decomposition of the salt. The most pronounced differences between the pristine and the charged sample $(4.7 \mathrm{~V})$ are visible in O1s and P2p spectra. The O1s spectrum of the charged sample shows appearance of two new peaks at $532.6 \mathrm{eV}$ and $534 \mathrm{eV}$. Carbonate and ether species are known to appear at these binding energies in O1s spectra, however, such significant contributions from these two peaks to O1s spectrum cannot be solely assigned to minor solvent decomposition observed in C1s spectrum. Therefore, these two peaks cannot be assigned to electrolyte decomposition, and instead, suggest formation of new O-containing compounds likely formed from the active material, which do not have $\mathrm{C}$ or $\mathrm{F}$ in their structure.

[a] Dr. R. Younesi, A. Christiansen, S. Loftager, Dr. J.M. García-Lastra, Prof. T. Vegge, Dr. P. Norby, Prof. P. Holtappels Department of Energy Conversion and Storage, Technical University of Denmark, DK-4000 Roskilde, Denmark E-mail: reyo@dtu.dk 

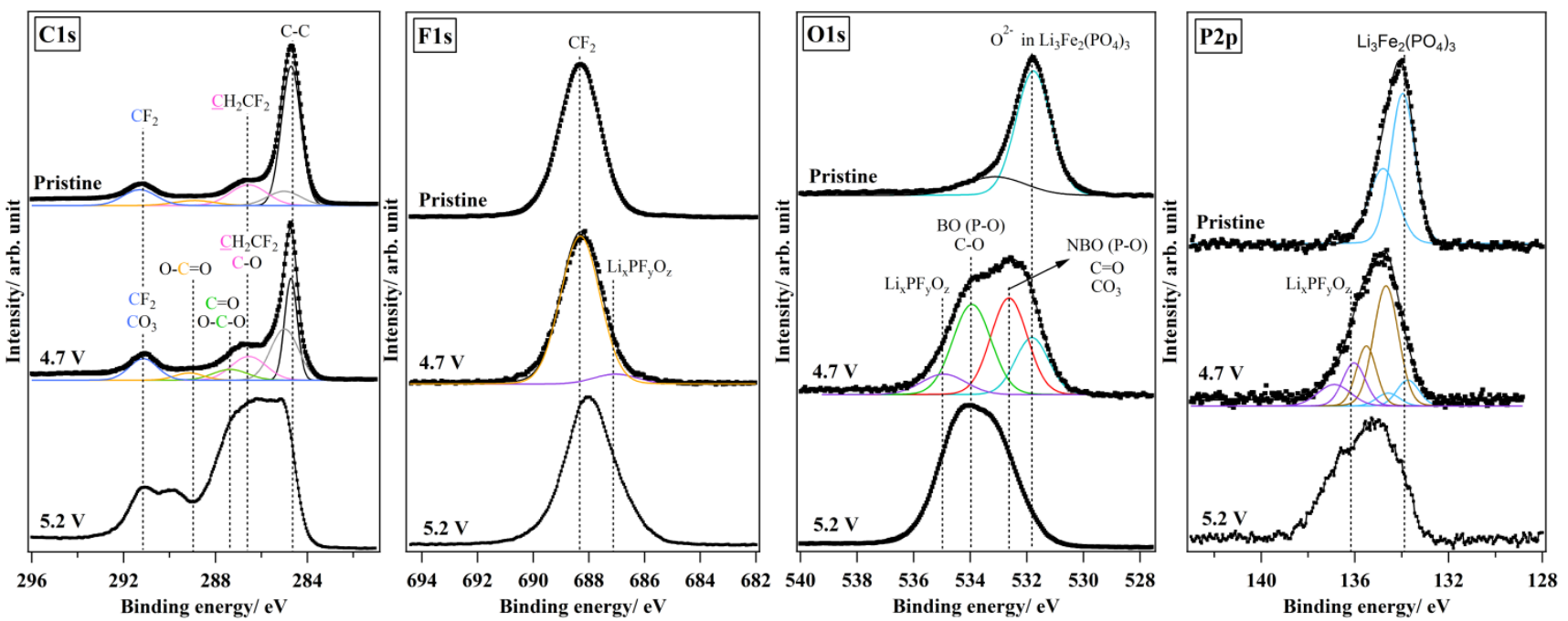

Figure 2. HAXPES spectra of pristine and charged $(4.7 \mathrm{~V}$ and $5.2 \mathrm{~V}) \mathrm{Li}_{3} \mathrm{Fe}_{2}\left(\mathrm{PO}_{4}\right)_{3}$ electrodes, measured by photon energy of 2010 eV.

Similarly, the P2p spectrum of the charged sample confirm the hypothesis of formation of new compounds originating from the pristine active material: The P2p spectrum of the charged sample shows appearance of a new doublet-peak at $134.7 \mathrm{eV}$ (between the $\mathrm{Li}_{3} \mathrm{Fe}_{2}\left(\mathrm{PO}_{4}\right)_{3}$ and $\mathrm{Li}_{x} \mathrm{PF}_{y} \mathrm{O}_{z}$ peaks at $133.9 \mathrm{eV}$ and $136.2 \mathrm{eV}$, respectively). The new peaks in the O1s and $\mathrm{P} 2 \mathrm{p}$ spectra of the charged sample are situated at higher binding energies compared to the peak of pristine material, implying that $\mathrm{O}$ and $\mathrm{P}$ have higher oxidation state and/or more electronegative neighbor compounds compared to $\mathrm{O}$ and $\mathrm{P}$ in the pristine active material. The new compounds could be referred to as non-bridging and bridging P-O bonds that show similar features in O1s spectra of polyphosphates ${ }^{[11]}$, but with higher oxidation state of $O$ compared to poly-phosphates. The pristine material actually contains only nonbridging bonds between $\mathrm{P}^{5+}$ and $\mathrm{O}^{2-}$, however, the appearance of new $\mathrm{O}$ peaks at higher binding energies indicates that $\mathrm{P}$ is bonded to $\mathrm{O}^{\delta-}$ with $\delta<2$ via non-bridging and bridging bonds. Similar behavior has been reported for layered oxide cathode materials undergoing oxidation changes in $\mathrm{O}$ atoms.$^{[12,13]}$ This is also in agreement with Mössbauer spectroscopy results showing no evidence of $\mathrm{Fe}^{4+}$ formation after charging $\mathrm{Li}_{3} \mathrm{Fe}_{2}\left(\mathrm{PO}_{4}\right)_{3}$ to $5 \mathrm{~V}^{\left[{ }^{[8]}\right.}$ Moreover the instability of the $\mathrm{Fe}^{4+}$ oxidation state has also been observed in other materials like iron oxoperovskites $\left(\mathrm{BaFeO}_{3}\right.$ and $\left.\mathrm{SrFeO}_{3}\right)$ where the iron nominal oxidation should be +4 . However, the $(\mathrm{FeO})^{8-}$ octahedral complexes in these oxoperovskites exhibit a Fe ${ }^{3+}\left(\mathrm{O}_{6}\right)^{11-}$ nature rather than the expected $\mathrm{Fe}^{4+}\left(\mathrm{O}_{6}\right)^{12-}$ (i.e., a hole is transferred from the iron to its oxygen ligands). ${ }^{[14]}$

Further charging of $\mathrm{Li}_{3} \mathrm{Fe}_{2}\left(\mathrm{PO}_{4}\right)_{3}$ cells to $5.2 \mathrm{~V}$ resulted in decomposition of electrolyte. The $\mathrm{C} 1 \mathrm{~s}$ spectrum of $5.2 \mathrm{~V}$ sample clearly shows pronounced peaks originated from the decomposition of the solvent. The F1s and P2p spectra of $5.2 \mathrm{~V}$ also indicate degradation of $\mathrm{LiPF}_{6}$.

In order to understand the HAXPES-measured shift of the 1 s level of the oxygen ions in $\mathrm{Li}_{3} \mathrm{Fe}_{2}\left(\mathrm{PO}_{4}\right)_{3}$ during delithiation, DFT calculations were performed.

Figure 3. (a) Rhombohedral unit cell of $\mathrm{Li}_{3} \mathrm{Fe}_{2}\left(\mathrm{PO}_{4}\right)_{3}$ showing the blue $\mathrm{Li}$ ion which upon extraction induces a hole primarily in the green $\mathrm{O}$ ion. For the other ions, $\mathrm{Li}$ ions are purple, $\mathrm{Fe}$ ions are brown, $\mathrm{P}$ ions are yellow and $\mathrm{O}$ ions are red. (b) Mulliken-charge difference between a rhombohedral unit cell of $\mathrm{Li}_{3} \mathrm{Fe}_{2}\left(\mathrm{PO}_{4}\right)_{3}$ in its pristine phase and one containing a $\mathrm{Li}$ vacancy. The $\mathrm{O}$ ion with the most significant moment change is enclosed by a red circle and this is the same atom enclosed in (c). (c) Core-level energies of 1 s orbitals of $O$. (d) Mulliken-charge difference between a monoclinic unit cell of $\mathrm{Li}_{3} \mathrm{~V}_{2}\left(\mathrm{PO}_{4}\right)_{3}$ in its pristine phase and one containing a Li vacancy. a)

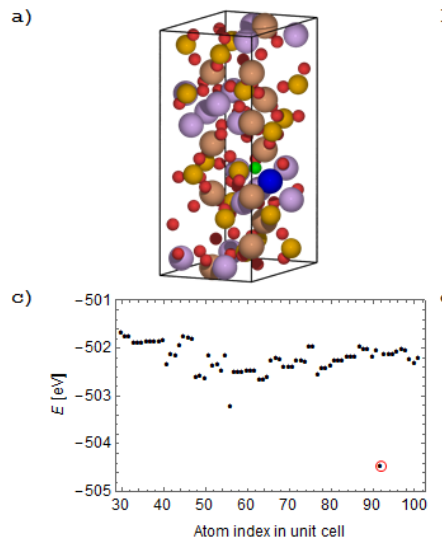

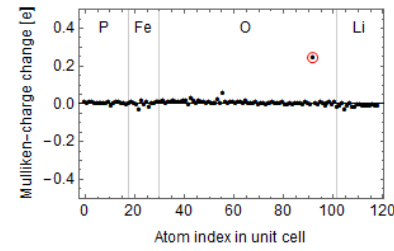

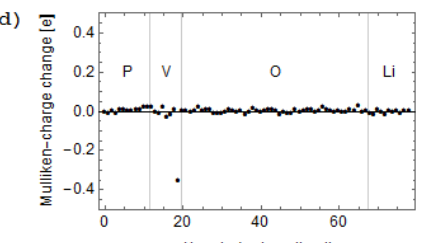

The rhombohedral unit cell of $\mathrm{Li}_{3} \mathrm{Fe}_{2}\left(\mathrm{PO}_{4}\right)_{3}$ shown in Figure 3(a) contains 6 formula units yielding a total of 120 atoms. All the $\mathrm{Li}$ ions in the unit cell occupy an equivalent Wyckoff position. Hence the effect upon Li extraction (the blue ion in Figure 3(a)) does not depend on the specific Li site being vacated. In Figure 3(b), the change in the Mulliken charge upon extraction of one Li ion is shown. From this result, no oxidation of the Fe ions upon delithiation is predicted to occur and a hole is not found to localize in the Fe ions. Instead, a limited number of the $\mathrm{O}$ ions are seen to change their Mulliken charges. This corresponds to an oxidation of some of the $\mathrm{O}$ ions from $\mathrm{O}^{2-}$ to $\mathrm{O}^{\delta-}$ with $\delta<2$. In particular, one $\mathrm{O}$ ion (the green ion in Figure 3(a)) residing close to the Li vacancy is seen to remarkably change its Mulliken charge by 0.25 e.

The result of a calculation of the electronic levels of the 1 s orbitals of the $\mathrm{O}$ ions in the unit cell is shown in Figure 3(c). From this, a clear shift of 1 s electron residing on the same $O$ ion which had its Mulliken charge significantly changed is seen (compare Figure 3(b) and Figure 3(c)). Hence, from a computational point of view, a hole is predicted to localize in a limited number of $O$ ions, mainly in one, as a Li vacancy is created during delithiation. This could explain the shift of about $2 \mathrm{eV}$ observed in the HAXPES spectrum. 
The monoclinic crystal system of $\mathrm{Li}_{3} \mathrm{Fe}_{2}\left(\mathrm{PO}_{4}\right)_{3}$ was also investigated and the very same hole localization in the $\mathrm{O}$ ions was observed, showing no dependence of the crystal system on the oxidation mechanism in $\mathrm{Li}_{3} \mathrm{Fe}_{2}\left(\mathrm{PO}_{4}\right)_{3}$.

It could be argued that the localization of the holes upon Li extraction is an artifact stemming from applying the $U$ correction to the $\mathrm{p}$ orbitals of the $\mathrm{P}$ and $\mathrm{O}$ ions (See the experimental section for more details). In order to show that this is not the case, monoclinic $\mathrm{Li}_{3} \mathrm{~V}_{2}\left(\mathrm{PO}_{4}\right)_{3}$ was also investigated. Here it is well-known that the oxidation during delithiation takes place on the $\mathrm{V}$ ions. ${ }^{[15]}$

The changes in the Mulliken charges in a monoclinic unit cell of $\mathrm{Li}_{3} \mathrm{~V}_{2}\left(\mathrm{PO}_{4}\right)_{3}$ after introducing one Li vacancy are shown in Figure 3(d). Upon creation of a Li vacancy, the magnetic moments of the $O$ ions are not changed as compared to the fully pristine phase. Instead, the Mulliken charge of a single $\mathrm{V}$ ion increases by 0.30 e (a similar change to that of the $\mathrm{O}$ ion depicted in green in Fig $3 a$ for $\left.\mathrm{Li}_{3} \mathrm{Fe}_{2}\left(\mathrm{PO}_{4}\right)_{3}\right)$. Hence, in agreement with literature ${ }^{[15]}$, in $\mathrm{Li}_{3} \mathrm{~V}_{2}\left(\mathrm{PO}_{4}\right)_{3}$, oxidation takes place at the $\mathrm{V}$ ions during delithiation. This substantiates the aforementioned DFT prediction of the hole localization in the $\mathrm{O}$ ions as being the active oxidation mechanism in $\mathrm{Li}_{3} \mathrm{Fe}_{2}\left(\mathrm{PO}_{4}\right)_{3}$.

In order to further prove the reliability of the present model, the structural changes during delithiation of rhombohedral $\mathrm{Li}_{x} \mathrm{Fe}_{2}\left(\mathrm{PO}_{4}\right)_{3}$ (from $x=3$ to 1 ) and monoclinic $\mathrm{Li}_{x} \mathrm{~V}_{2}\left(\mathrm{PO}_{4}\right)_{3}$ (from $x=3$ to 0 ) have also been investigated. The calculations show relative volume changes of $6 \%$ for $\mathrm{Li}_{x} \mathrm{~V}_{2}\left(\mathrm{PO}_{4}\right)_{3}$ (experimentally, $6 \%{ }^{[15]}$ ) and $1 \%$ for $\mathrm{Li}_{x} \mathrm{Fe}_{2}\left(\mathrm{PO}_{4}\right)_{3}$ (experimentally, $<1 \%{ }^{[8]}$ ) which are in excellent agreement with the experimental observations.

In summary, HAXPES analysis and DFT calculations revealed that the charging process of $\mathrm{Li}_{3} \mathrm{Fe}_{2}\left(\mathrm{PO}_{4}\right)_{3}$ is accompanied by changes in the oxidation states of the $\mathrm{O}$ ions rather than that of the Fe ions. The $\mathrm{O}^{2-}$ ions in pristine material acquired higher oxidation states $\left(\mathrm{O}^{\delta-}, \delta<2\right)$ while the oxidation state of the $\mathrm{Fe}^{3+}$ remained unchanged. These results, together with the failure in electrochemical cycling of $\mathrm{Li}_{3} \mathrm{Fe}_{2}\left(\mathrm{PO}_{4}\right)_{3}$ after the initial delithiation as well as the absence of major electrolyte decomposition, indicate that $\mathrm{Li}_{3} \mathrm{Fe}_{2}\left(\mathrm{PO}_{4}\right)_{3}$ undergoes irreversible structural changes when charged to high voltages of $4.7 \mathrm{~V}$.

\section{Experimental Section}

\section{Electrochemical characterizations}

Rhombohedral $\mathrm{Li}_{3} \mathrm{Fe}_{2}\left(\mathrm{PO}_{4}\right)_{3}(R \overline{3})$ was synthesized via ion exchange from $\alpha-\mathrm{Na}_{3} \mathrm{Fe}_{2}\left(\mathrm{PO}_{4}\right)_{3}$. Details on the synthesis can be found in ${ }^{[6]}$. Positive electrodes were prepared by coating a mixture of $\mathrm{Li}_{3} \mathrm{Fe}_{2}\left(\mathrm{PO}_{4}\right)_{3}$, Super $\mathrm{C} 65$ (Timcal), and PVdF (Aldrich) dissolved in N-Methyl-2-pyrrolidone on Al foil. A weight ratio of 50:25:25 was used. The electrodes were dried at $80{ }^{\circ} \mathrm{C}$, compressed by a role press, and punched into discs of $10 \mathrm{~mm}$ in diameter The active particle load was approx. $0.5 \mathrm{mg} / \mathrm{cell}$. The electrodes were then transferred to an Ar-filled glove box and dried in a vacuum furnace overnight at $120^{\circ} \mathrm{C}$. Li-ion cells with pouch cell configuration were assembled using Celgard separator, $200 \mu$ electrolyte of $1 \mathrm{M}$ LiPF $\mathrm{F}_{6}$ in ethylene carbonate:dimethylene carbonate (EC:DMC) (vol. 1:1), and Li foil as counter electrode. Electrochemical characterization was performed using a VMP3 Biologic multichannel potentiostat by charging cells to $4.7 \mathrm{~V}$ or $5.2 \mathrm{~V}$ with a current of $10 \mu \mathrm{A}$

\section{HAXPES measurements}

The samples were transported to the Helmholtz Centre, Berlin, Germany, in a vacuum-sealed polymer-coated aluminum bag, which was later opened in an Ar-filled glovebox at Bessy. The samples were washed with DMC, mounted on a specially designed vacuum transfer chamber, and transported to the analyzing chamber. The measurements were performed at the HIKE end station using fixed excitation energy of $2010 \mathrm{eV}$.

\section{Computational details}

In order to mechanism in the rhombohedral and monoclinic phases of $\mathrm{Li}_{3} \mathrm{Fe}_{2}\left(\mathrm{PO}_{4}\right)_{3}$ and the monoclinic phase of $\mathrm{Li}_{3} \mathrm{~V}_{2}\left(\mathrm{PO}_{4}\right)_{3}$ DFT calculations were performed on using the Vienna Ab initio Simulation Package code (VASP ${ }^{[16]}$. Following the work of Jain et al. ${ }^{[17]}$ we used the PBE+U exchangecorrelation functional, which includes an on-site Coulomb repulsion (Hubbard $U$ correction) of $U_{\mathrm{Fe}}=5.2 \mathrm{eV}$ to the Fe $3 \mathrm{~d}$ orbitals in $\mathrm{Li}_{3} \mathrm{Fe}_{2}\left(\mathrm{PO}_{4}\right)_{3}$ and $U_{\mathrm{V}}=3.25 \mathrm{eV}$ to the $\mathrm{V} 3 \mathrm{~d}$ orbitals in $\mathrm{Li}_{3} \mathrm{~V}_{2}\left(\mathrm{PO}_{4}\right)_{3}$ In addition, an on-site Coulomb repulsion of $U_{\mathrm{OP}}=5.2 \mathrm{eV}$ was applied to the $\mathrm{p}$ orbitals of the $\mathrm{P}$ and $\mathrm{O}$ ions. This was done in order to investigate whether electronic holes (created after removing a $\mathrm{Li}^{+}$ion during the delithiation) can localize in the phosphate ions. Although applying $U$ corrections on $p$ orbitals is less common than applying it on the d orbitals of transition metals, this approach has been shown to properly describe hole and electron localization in lithium peroxide and lithium carbonate in $\mathrm{Li}$-air batteries, using similar $U$-correction values. ${ }^{[18]}$ Due to the size of the unit cell, $\Gamma$-point calculations were sufficient to describe the system. A kinetic energy cutoff of $390 \mathrm{eV}$ was used. Corelevel electrons were treated using the Projector augmented-wave (PAW) method. ${ }^{[19]}$ The core electrons included until the $1 \mathrm{~s}$ shell for Li and $\mathrm{O}$, the $2 p$ shell for $\mathrm{P}$, and the $3 p$ shell for $\mathrm{V}$ and Fe. In a first step the lattice parameters and the internal coordinates of the systems were relaxed for the fully lithiated phases. When a single $\mathrm{Li}$ ion was removed the lattice parameters were fixed to those of the fully lithiated phase, relaxing only the internal coordinates. In all the calculations for $\mathrm{Li}_{3} \mathrm{Fe}_{2}\left(\mathrm{PO}_{4}\right)_{3}$ the total magnetic moment of the system was kept at a fixed value of $\mu_{\mathrm{tot}}=N_{\mathrm{Fe}} \cdot \mu_{\mathrm{Fe} 3+}-$ $N_{\text {extracted Li }} \mu_{\mathrm{B}}$, where $N_{\mathrm{Fe}}$ is the number of Fe ions in the unit cell, $N_{\text {extracted Li }}$ is the number of Li ions extracted from the unit cell, $\mu_{\mathrm{B}}$ is the Bohr magneton and $\mu_{\mathrm{Fe}^{3+}}$ is the magnetic moments corresponding to a $\mathrm{Fe}^{3+}$ ion in an octahedral high-spin configuration (i.e. $\mu_{\mathrm{Fe}^{3+}}=5 \mu_{\mathrm{B}}$ ). In this way, the created hole could, in principle, be localized in the $\mathrm{Fe}$ ions, i.e. the $\mathrm{Fe}^{3+}$ ions would become $\mathrm{Fe}^{4+}$ ions, passing their magnetic moment from $\mu_{\mathrm{Fe}^{3+}}=5 \mu_{\mathrm{B}}$ to $\mu_{\mathrm{Fe}^{4+}}=4 \mu_{\mathrm{B}}$. In all the calculations for $\mathrm{Li}_{3} V_{2}\left(\mathrm{PO}_{4}\right)_{3}$ we proceeded similarly, imposing a total magnetic moment of $\mu_{\mathrm{tot}}=N_{\mathrm{V}} \cdot \mu_{\mathrm{V}^{3+}}-N_{\mathrm{extracted} \mathrm{Li}} \mu_{\mathrm{B}}$, where $N_{\mathrm{V}}$ is the number of $\mathrm{V}$ ions in the unit cell and $\mu_{\mathrm{V}^{3}}=2 \mu_{\mathrm{B}}$. We checked that the effect of imposing the total magnetic moment on the systems has a negligible impact on the results. In order to do that we followed the next procedure: once the hole localization in the $\mathrm{O}$ ions of the calculation in which the magnetic moments of the $\mathrm{Fe}$ and $\mathrm{O}$ ions were anti-aligned was achieved, a calculation in which the moments of the $\mathrm{Fe}$ and $\mathrm{O}$ ions were alignedi.e. with fixed total magnetic moment to $\mu_{\mathrm{tot}}=N_{\mathrm{Fe}^{3+}} \cdot \mu_{\mathrm{Fe}^{3+}}+N_{\text {extracted Li }} \mu_{\mathrm{B}}$-was performed. This Fe-O moment alignment and the original Fe-O moment anti-alignment yielded nearly degenerate states.

The analysis of the change in the ionic charges was conducted following Mulliken criterion ${ }^{[20]}$. The shifts on the oxygen ions $1 \mathrm{~s}$ core levels in Fig. $3(\mathrm{f})$ were calculated using the initial state approximation (activated in VASP code by using the flag ICORELEVEL=1), which just involves recalculating the Kohn-Sham eigenvalues of the core states after a self-consistent calculation of the valence charge density. ${ }^{[16]}$ 
For the DFT analysis of the structural changes upon fully delithiation (i.e. passing from $x=3$ to 1 in $\mathrm{Li}_{x} \mathrm{Fe}_{2}\left(\mathrm{PO}_{4}\right)_{3}$ and (from $x=3$ to 0 in $\left.\mathrm{Li} \mathrm{V}_{2}\left(\mathrm{PO}_{4}\right)_{3}\right)$ the same computational parameters as in the analysis of the oxidation mechanism were used with the exception of allowing also the unit-cell parameters of the fully delithiated phases to relax to their equilibrium values.

\section{Acknowledgements}

We sincerely thank Prof. Kristina Edström for letting us performing HAXPES measurements using beam time allotted to Uppsala University. We are also grateful to Dr. Mihaela Gorgoi at the Helmholtz Centre, Berlin, for support with the HAXPES measurements. The research leading to these results has received funding from the European Union's Seventh Framework Programme (FP7/20072013) under grant agreement $n^{\circ} 608575$. JMGL acknowledges support from the Spanish Ministry of Economy and Competitiveness under Projects FIS2012-30996 and FIS2013-46159-C3-1-P and from the Villum Foundation's Young Investigator Programme $\left(4^{\text {th }}\right.$ round, project: In silico design of efficient materials for next generation batteries. Grant number: 10096).

Keywords: Polyanionic cathodes $•$ NASICON • lithium batteries $\bullet$ Oxygen oxidation state $\bullet$ HAXPES

[1] C. Masquelier, L. Croguennec, Chem. Rev. 2013, 113, 6552-6591.

[2] X. H. Rui, C. Li, C. H. Chen, Electrochim. Acta 2009, 54, 3374-3380.

[3] K. Nanjundaswamy, A. Padhi, J. Goodenough, S. Okada, H. Ohtsuka,

[4] C. Masquelier, A. Padhi, K. Nanjundaswamy, J. Goodenough, J. Solid State Chem. 1998, 135, $228-234$

[5] A. S. Andersson, B. Kalska, P. Eyob, D. Aernout, L. Häggström, J. O. Thomas, Solid State Ionics 2001, 140, 63-70.

[6] M. Morcrette, C. Wurm, C. Masquelier, Solid State Sci. 2002, 4, 239-246.

[7] J. Cabana, J. Shirakawa, M. Nakayama, M. Wakihara, C. P. Grey, J. Mater. Chem. 2011, $21,10012$.

[8] A. S. Christiansen, R. E. Johnsen, P. Norby, C. Frandsen, S. Morup, S. H. Jensen, K. K. Hansen, P. Holtappels, J. Electrochem. Soc. 2015, 162, A531-A537.

[9] R. Younesi, A. S. Christiansen, R. Scipioni, D.-T. Ngo, S. B. Simonsen, K. Edström, J. Hjelm, P. Norby, J. Electrochem. Soc. 2015, 162, A1289-A1296.

[10] R. Younesi, M. Hahlin, M. Treskow, J. Scheers, P. Johansson, K. Edström, J. Phys. Chem. C 2012, 116, $18597-18604$.

[11] M. Crobu, A. Rossi, F. Mangolini, N. D. Spencer, Anal. Bioanal. Chem. 2012, 403, $1415-1432$.

[12] A. R. Armstrong, M. Holzapfel, P. Novák, C. S. Johnson, S.-H. Kang, M. M. Thackeray, P. G. Bruce, J. Am. Chem. Soc. 2006, 128, 8694-8698.

[13] M. Sathiya, A. M. Abakumov, D. Foix, G. Rousse, K. Ramesha, M. Saubanère, M. L. Doublet, H. Vezin, C. P. Laisa, a S. Prakash, et al., Nat. Mater. 2015, 14, 230-238.

[14] N. Hayashi, T. Yamamoto, H. Kageyama, M. Nishi, Y. Watanabe, T. Kawakami, Y. Matsushita, A. Fujimori, M. Takano, Angew. Chemie 2011, 123, 12755-12758.

[15] J. Yoon, S. Muhammad, D. Jang, N. Sivakumar, J. Kim, W. H. Jang, Y. S. Lee, Y. U. Park, K. Kang, W. S. Yoon, J. Alloys Compd. 2013, 569, 76-81.

[16] G. Kresse, J. Furthmüller, Comput. Mater. Sci. 1996, 6, 15-50.

[17] A. Jain, S. P. Ong, G. Hautier, W. Chen, W. D. Richards, S. Dacek, S. Cholia, D. Gunter, D. Skinner, G. Ceder, et al., APL Mater. 2013, 1, -

[18] J. M. Garcia-Lastra, J. S. G. Myrdal, R. Christensen, K. S. Thygesen, T. Vegge, J. Phys. Chem. C 2013, 117, 5568-5577.

[19] P. E. Blöchl, Phys. Rev. B 1994, 50, 17953-17979.

[20] R. S. Mulliken, J. Chem. Phys. 1955, 23, 1833. 